\title{
An Investigation into the Effect of Psychological Empowerment on Brand Equity (Case Study: Islamic Azad University, Bandar Abbas Branch)
}

\author{
Masoud Dehghani \\ Department of Management, College of Economic \& Management, Bandar Abbas Branch, Islamic Azad
}

\begin{tabular}{l} 
Keywords: \\
Psychological \\
Empowerment, Brand Equity, \\
Islamic Azad University- \\
Bandar Abbas Branch \\
\hline Received \\
04 April 2018 \\
Received in revised form \\
28 October 2018 \\
Accepted \\
03 November 2018 \\
\hline Correspondence: \\
dehghani.masoud911088033@ \\
yahoo.com
\end{tabular}

\author{
ABSTRACT
}

The aim of this research is to investigate the effect of psychological empowerment on brand equity in Islamic Azad University, Bandar Abbas branch. The survey-correlational was employed in data collection. The statistical population of this study includes two populations, i.e., professors and staff and students of different colleges. To select the participants, random stratified sampling method using Cochran's Formula was used. The standard questionnaires of Spreitzer and Mishra (1997) and Kim and Hyun (2011) were used to measure psychological empowerment and brand equity, respectively. The results indicated that all the psychological empowerment dimensions of the staff and professors of the university are valid enough to increase brand equity from the aspect of empowerment indices.

(C)AIMI Journals

Empowerment refers to encouraging people to cooperate in making decisions that affect their activities so that they can come up with good ideas and put them into action. Empowerment is the vital factor of business in the modern world. Goals such as getting closer to the customer, improving after-sales services, introducing innovation continually, increasing productivity, developing knowledge strategies, and leading the field will be accomplished by organizations that have found new ways to empower their employees (Toutian Esfahani, 2014). 
The role of efficient human force in accomplishing the goals of an organization is obvious and undeniable and there is no doubt that the national wealth of a country or in other words, its human capital appears as skills, organizations, and motivation. In order to apply the human force as much as possible, managers should identify the motivational factors that can motivate the human force and attempt to align it with the goals of the organization.

\section{Theoretical Foundations}

Nowadays, the previous methods of human resource management are challenged and the ground for modern attitudes in human resources is prepared. This has led to further attention to use the human resources properly. The skilled and able human force is one of the most important factors of the dynamism of societies and organizations. Therefore, organizations are obliged to provide, retain, and manage efficient human resources to develop their tasks. Smart managers are aware that if they invest in developing and enhancing human force, they will guarantee the success, efficiency, and competitive advantage of their organization. The most effective way to gain competitive advantage in the current situation regarding the modern attitudes is to empower human resources of the organizations (Mohammadi, 2009). Since empowerment is one of the attitudes that has led to positive and various revolutions in employees' working, in today's uncertain conditions, the organization has no choice but to use its human force appropriately. The only way to keep a balance of the organization is to empowering the employees (Miri \& Sabzikaran, 2011). In fact, empowerment as a tool aligns individual goals with organizational goals and develops human's potential capacities and as a concept provides the benefits of the organization and gives the employees a sense of ownership and pride. Empowerment includes various types such as physical, mental, social, spiritual, environmental, educational, occupational, etc. The most important type is the psychological empowerment.

In fact, psychological empowerment as a modern internal motivational approach refers to releasing people's inner forces and power and creating opportunities to nurture employees' talents, abilities, and competencies. Furthermore, psychological empowerment develops a positive attitude towards the career and organization. It also trains motivated and able managers to allow the organization to show sensible reactions to the dynamism of the competitive environment (Navehebrahim \& Abdollahi, 2007). The empowerment has necessitated broad environmental changes and flexibility of organizations in order to ensure their survival and giving employees freedom of action. This is one of the fundamental strategies to increase productivity as well as rapid adaptability and ensure the survival of today's organizations.

Psychological empowerment has gained considerable importance (Goudarzi \& Gominian, 2002). Psychological empowerment includes five cognitive elements: meaningfulness, selfefficacy, autonomy, effectiveness, and trust (Thomas \& Velthouse, 1990). One of the other factors that affect the brand equity of a product or service is the psychological empowerment of human resources by relying on the growth of their related dimensions in such a way that employees discover their inner potential talents in a desirable work environment and under organizational supports, and improve internal motivation in order to align their personal goals with organizational goals and create an ideal mental image of the organization's brand. 
Brand is one of the intangible assets of any company that holds the highest value. Today, brand is the main capital of most businesses whose record is publicly endowed with value. For decades, the values of organizations were measured according to the estates, equipment, factories, and tangible assets. However, it has been concluded that the real value of an organization lies in potential and actual customers' minds. Brand equity refers to the features and reputations of a brand that can increase or decrease the value added by the product for customers and organizations (Aaker \& Joachimsthaler, 2009). When a product is branded, it is considered more valuable than before; this value refers to brand equity (Keller, 1993). When the brand equity of a product is high enough, target buyers react positively to that product, for example, they pay more, buy it repeatedly, exhibit entertaining behavior, etc. (Keller, 2008). This may also lead to higher income, lower costs, and higher profit and have a direct effect on the ability of the organization to make right decisions about increasing the prices of products, effectiveness of marketing communications, and success in commercial development. Therefore, by strengthening the brand, the competitive position and financial performance of a company will be enhanced. Note that the importance of brand equity is not limited to what has been said before and it can be applied to managers' future planning and decisions. However, psychologically, spiritually, and socially empowered employees are also required. Today, brand management is a concern for the managers and decision-makers of organizations and companies. According to the studies on this subject, brand can affect the performance, profitability, business value, cost reduction, unreliability, etc. Today, in most developed countries, brand is considered as one of the principal organizational capitals, thus brand management holds an important managerial position in the structure of today's organizations. Brand management is a useful tool in marketing managers' hands in order to formulate marketing strategies and plans. Brand equity is one of the most important concepts of influencer marketing that helps the organization to identify its competitive position. In recent years, brand equity has drawn attention (Van Osselaer \& Alba, 2000; Yoo, Donthu \& Lee, 2000). Brand equity is of great importance due to its qualitative content when the customer processes the information of a particular product (Krishnan \& Hartline, 2001).

Since Iran is a developing country, studies on marketing and brand can develop the industry and business because in today's competitive world, brands are selling. Marketing managers in Iran should consider that quality and services which are as important as brand and trademark and they are effective in competitive advantage and customers' loyalty. In this regard, all the organizations in Iran especially important educational centers such as Islamic Azad University, Bandar Abbas branch are required to create powerful brand equity in order to increase market share, develop future plans, and keep eager-to-learn students as loyal customers and increase them so that they can use them as sustainable competitive advantage against their rivals. Therefore, the present study attempts to investigate the effect of psychological empowerment on brand equity in Islamic Azad University, Bandar Abbas branch.

\section{Hypotheses}

The primary hypothesis of this study expresses that psychological empowerment has a positive and significant effect on brand equity of Islamic Azad University, Bandar Abbas 
branch. In five other hypotheses (secondary hypotheses), the effect of the components of psychological empowerment (i.e., merit, meaningfulness, autonomy, effectiveness, and trust) on brand equity of Islamic Azad University, Bandar Abbas branch will be measured.

\section{Conceptual Framework}

The conceptual model of a research is a basis that the whole research is based upon (Hafeznia, 2013). After studying the previous models (Bowen \& Lawler, 1992; Hayes \& Ninemeier, 2008; Laverack, 2006; McLagan \& Nel, 1992; Noller, 1991; Robbins, Crino \& Fredendall, 2002) and according to the literature on empowerment, all its factors (including merit, meaningfulness, autonomy, effectiveness, and trust) were considered independent variables and brand equity was considered dependent variable (Figure 1).

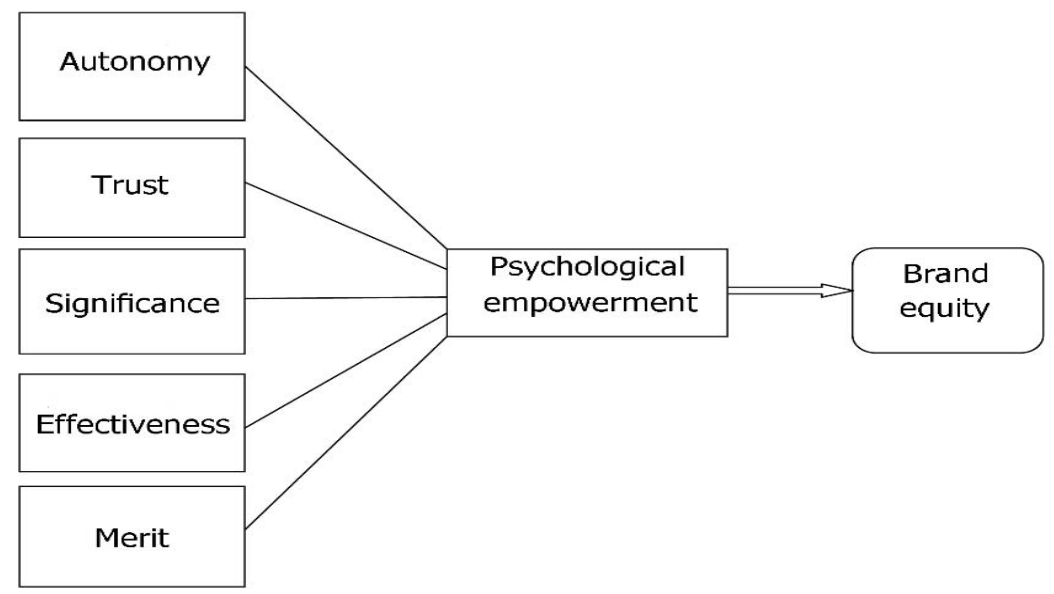

Figure 1. The conceptual model of the research with the emphasis on factors affecting brand equity

\section{Method}

The present study is survey-correlational. Since it attempts to solve a particular problem in the society, it is applicable in terms of its aim. The unit of analysis in this research is person. The statistical population of this study includes two independent groups. The first group is the professors and the staff by which the psychological empowerment of university employees as an internal effective factor to increase brand equity is measured. Therefore, this group includes 412 members of Islamic Azad University, Bandar Abbas branch such as all the faculty members as the teaching personnel (line) and the employees of different sections such as finance, services, education, etc. (staff). The second group includes 16391 people which considers the students of the university as an external factor and believes that the enhancement of brand equity is based on the attitude of educational service customers.

Random stratified sampling was the most appropriate sampling method for the first group. In random stratified sampling, the people of population are categorized into different groups according to their characteristics within the group and samples are selected proportionally. The groups of first statistical population were homogeneous and categorized into two subgroups of staff (all the employees of different sections such as finance, services, education, research, administration, etc.) and line (all the faculty members as the teaching personnel, adjunct professors, and visiting professors). Table 1 presents the share ratio of first statistical 
population sub-categories. Table 2 shows the share ratio of second statistical population subcategories.

Table 1

The Share Ratio of First Statistical Population Sub-Categories

\begin{tabular}{lccccc}
\hline & Percentage & Number & & Percentage & Number \\
\hline Line & $34 \%$ & 66 & Staff & $66 \%$ & 134 \\
\hline
\end{tabular}

Table 2

The Share Ratio of Second Statistical Population Sub-Categories

\begin{tabular}{lcclcc}
\hline & Percentage & Number & & Percentage & Number \\
\hline Faculty of Humanities & $53 \%$ & 199 & Faculty of Natural Resources & $2 \%$ & 7 \\
Faculty of Basic Sciences & $2 \%$ & 7 & Faculty of Medicine & $3 \%$ & 11 \\
Faculty of Engineering & $33 \%$ & 124 & Faculty of Art and Architecture & $7 \%$ & 27 \\
\hline
\end{tabular}

Determining the sample size is of great importance because the results are generalized to the population. Therefore, the questionnaire is distributed among all the categories of the population proportionally. The sample size of both statistical populations has been calculated using Cochran's Formula as the following:

The sample size of first population:

$$
n=\frac{N t^{2} \cdot p(p-1)}{N d^{2}+t^{2} p(p-1)}=\frac{412(1 / 96)^{2} \cdot 0 / 5(0 / 5)}{412(\% 5)^{2}+(1 / 96)^{2} \cdot 0 / 5(0 / 5)}=200
$$

The sample size of second population:

$$
n=\frac{N t^{2} \cdot p(p-1)}{N d^{2}+t^{2} p(p-1)}=\frac{16391(1 / 96)^{2} \cdot 0 / 5(0 / 5)}{16391(\% 5)^{2}+(1 / 96)^{2} \cdot 0 / 5(0 / 5)}=375
$$

\section{The Confirmative Factor Analysis of Variables}

In inferential analysis, before testing the hypotheses, we must test the validity of structure using confirmative factor analysis test. In goodness of fit test in confirmative analysis and path, the index of RMSEA or root mean square error of approximation is less than 8 percent, the index of $\frac{x^{2}}{d f}$ is less than 3 percent and (GFH, CFL, IFI, NNFI) is more than 90 percent. If the t-value of significance coefficients for each variable is more than 1.96 and less than -1.96 , the model has a strong fit. Since the output of software is unchanged in this part, the abbreviations of observed and latent variables are presented in Table 3.

Table 3

A Guide to Identify the Abbreviations of Variables

\begin{tabular}{llllll}
\hline Index & Question & Abbreviation & Index & Question & Abbreviation \\
\hline Autonomy & $1-5$ & Autonomy & Significance & $16-20$ & Significance \\
Effectiveness & $6-10$ & Effectiveness & Trust & $21-25$ & Trust \\
Merit & $11-15$ & Merit & Brand equity & $1-10$ & Brand equity \\
\hline
\end{tabular}




\section{The Measurement Model of Psychological Empowerment}

Tables 4 and 5 indicate the measurement model of psychological empowerment dimensions at standard and significance level. As presented in these tables, the membership of all the studied factors has been confirmed.

Table 4

The Measurement Model of Psychological Empowerment Dimensions Using Factor Analysis at Standard Level

\begin{tabular}{|c|c|c|c|}
\hline & Questions & Factor loading & $\begin{array}{l}\text { Result of membership } \\
\text { (factor loading }>0.3 \text { ) }\end{array}$ \\
\hline \multirow{5}{*}{ Autonomy } & Q1 & 0.70 & Accepted \\
\hline & Q2 & 0.70 & Accepted \\
\hline & Q3 & 0.61 & Accepted \\
\hline & Q4 & 0.63 & Accepted \\
\hline & Q5 & 0.53 & Accepted \\
\hline \multirow{5}{*}{ Effectiveness } & Q6 & 0.71 & Accepted \\
\hline & Q7 & 0.77 & Accepted \\
\hline & Q8 & 0.69 & Accepted \\
\hline & Q9 & 0.48 & Accepted \\
\hline & Q10 & 0.70 & Accepted \\
\hline \multirow{5}{*}{ Merit } & Q11 & 0.64 & Accepted \\
\hline & Q12 & 0.71 & Accepted \\
\hline & Q13 & 0.68 & Accepted \\
\hline & Q14 & 0.38 & Accepted \\
\hline & Q15 & 0.69 & Accepted \\
\hline \multirow{5}{*}{ Significance } & Q16 & 0.68 & Accepted \\
\hline & Q17 & 0.72 & Accepted \\
\hline & Q18 & 0.46 & Accepted \\
\hline & Q19 & 0.37 & Accepted \\
\hline & Q20 & 0.63 & Accepted \\
\hline \multirow{5}{*}{ Trust } & Q21 & 0.71 & Accepted \\
\hline & Q22 & 0.68 & Accepted \\
\hline & Q23 & 0.43 & Accepted \\
\hline & Q24 & 0.41 & Accepted \\
\hline & Q25 & 0.56 & Accepted \\
\hline
\end{tabular}

Table 5

The Measurement Model of Psychological Empowerment Dimensions Using Factor Analysis at Significance Level

\begin{tabular}{|c|c|c|c|}
\hline & Questions & Factor loading & $\begin{array}{l}\text { Result of membership } \\
\text { (T-value }>1.96)\end{array}$ \\
\hline \multirow{5}{*}{ Autonomy } & Q1 & 10.56 & Accepted \\
\hline & Q2 & 10.45 & Accepted \\
\hline & Q3 & 8.85 & Accepted \\
\hline & Q4 & 7.47 & Accepted \\
\hline & Q5 & 9.72 & Accepted \\
\hline \multirow{4}{*}{ Effectiveness } & Q7 & 12.26 & Accepted \\
\hline & Q8 & 10.59 & Accepted \\
\hline & Q9 & 6.82 & Accepted \\
\hline & Q10 & 10.77 & Accepted \\
\hline \multirow{2}{*}{ Merit } & Q14 & 5.26 & Accepted \\
\hline & Q15 & 10.58 & Accepted \\
\hline \multirow{3}{*}{ Significance } & Q16 & 9.86 & Accepted \\
\hline & Q17 & 10.49 & Accepted \\
\hline & Q18 & 6.16 & Accepted \\
\hline
\end{tabular}




\begin{tabular}{|c|c|c|c|}
\hline & Q19 & $\begin{array}{l}3.51 \\
9.00\end{array}$ & $\begin{array}{l}\text { Accepted } \\
\text { Accepted }\end{array}$ \\
\hline \multirow{5}{*}{ Trust } & Q20 & $\frac{9.00}{1085}$ & $\begin{array}{l}\text { Accepted } \\
\text { Accented }\end{array}$ \\
\hline & Q22 & 9.31 & Accepted \\
\hline & Q23 & 6.12 & Accepted \\
\hline & Q24 & 5.69 & Accepted \\
\hline & Q25 & 8.16 & Accepted \\
\hline
\end{tabular}

\section{The Measurement Model of Brand Equity}

Tables 6 and 7 indicate the measurement model of brand equity at standard and significance level. As shown in these tables, the membership of all the studied factors has been confirmed.

Table 6

The Measurement Model of Brand Equity Using Factor Analysis at Standard Level

\begin{tabular}{|c|c|c|c|}
\hline & Questions & Factor loading & $\begin{array}{l}\text { Result of membership } \\
\text { (factor loading }>0.3 \text { ) }\end{array}$ \\
\hline \multirow[t]{10}{*}{ Brand equity } & Q1 & 0.63 & Accepted \\
\hline & Q2 & 0.71 & Accepted \\
\hline & Q3 & 0.75 & Accepted \\
\hline & Q4 & 0.77 & Accepted \\
\hline & Q5 & 0.28 & Accepted \\
\hline & Q6 & 0.61 & Accepted \\
\hline & Q7 & 0.52 & Accepted \\
\hline & Q8 & 0.56 & Accepted \\
\hline & Q9 & 0.55 & Accepted \\
\hline & Q10 & 0.49 & Accepted \\
\hline
\end{tabular}

Table 7

The Measurement Model of Brand Equity Using Factor Analysis at Significance Level

\begin{tabular}{lccc}
\hline & Questions & Factor loading & $\begin{array}{c}\text { Result of membership (T- } \\
\text { value> 1.96) }\end{array}$ \\
\hline Brand equity & Q1 & 0.63 & Accepted \\
& Q2 & 0.71 & Accepted \\
& Q3 & 0.75 & Accepted \\
& Q4 & 0.77 & Accepted \\
& Q5 & 0.28 & Accepted \\
& Q6 & 0.61 & Accepted \\
& Q7 & 0.52 & Accepted \\
& Q8 & 0.56 & Accepted \\
& Q9 & 0.55 & Accepted \\
& Q10 & 0.49 & Accepted \\
\hline
\end{tabular}

\section{Hypotheses Test Using Structured Linear Relationships}

After determining the measurement models to evaluate the conceptual model, examining the existence of causal relationship between the variables, and investigating the proportion of observed data to the conceptual model, research hypotheses were tested using structural equations model. The results of hypotheses test are illustrated in Figure 2 and 3. Table 8 shows the goodness of fit indices of conceptual model. 


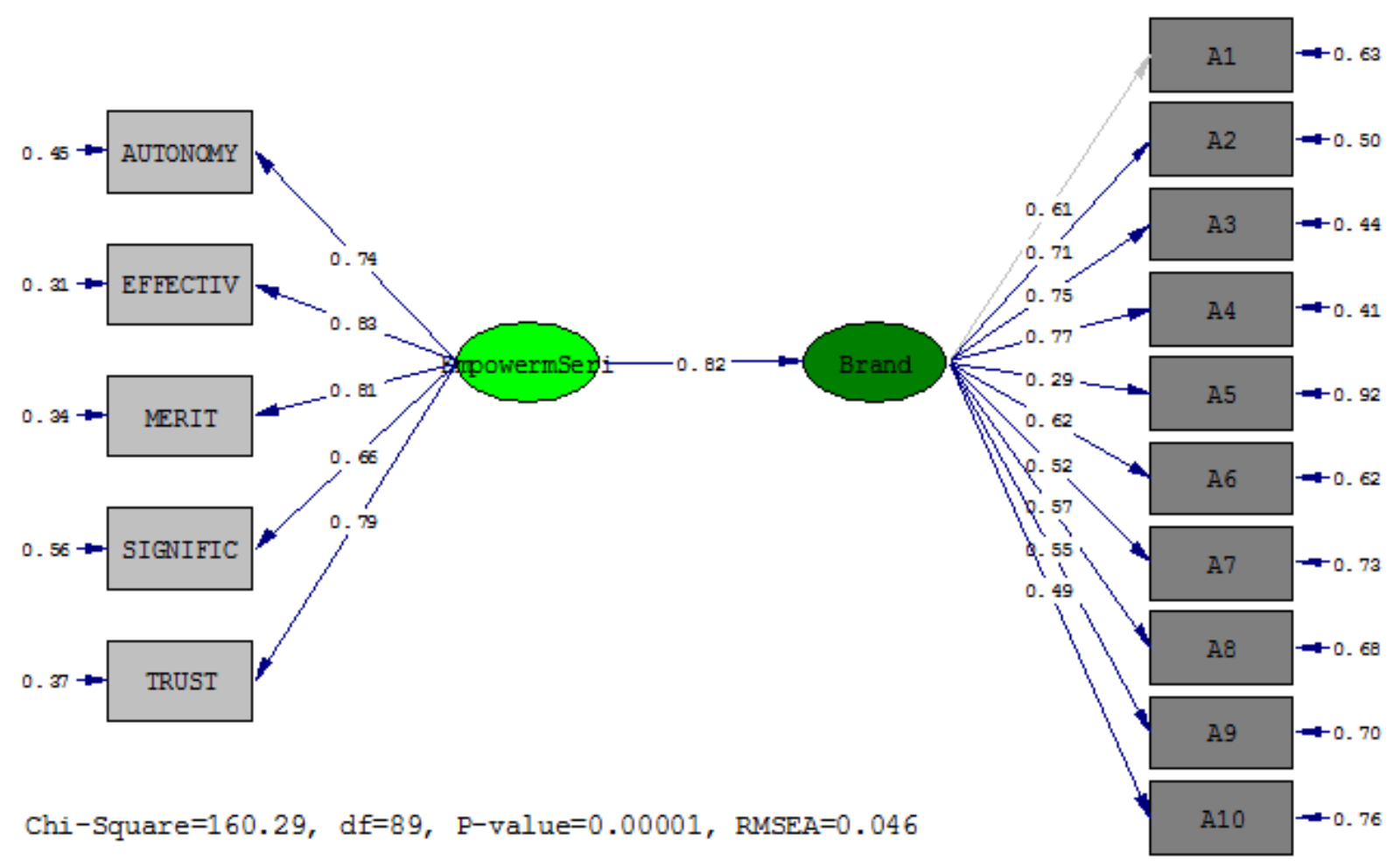

Figure 2. Measuring the general model and hypotheses results at standard level

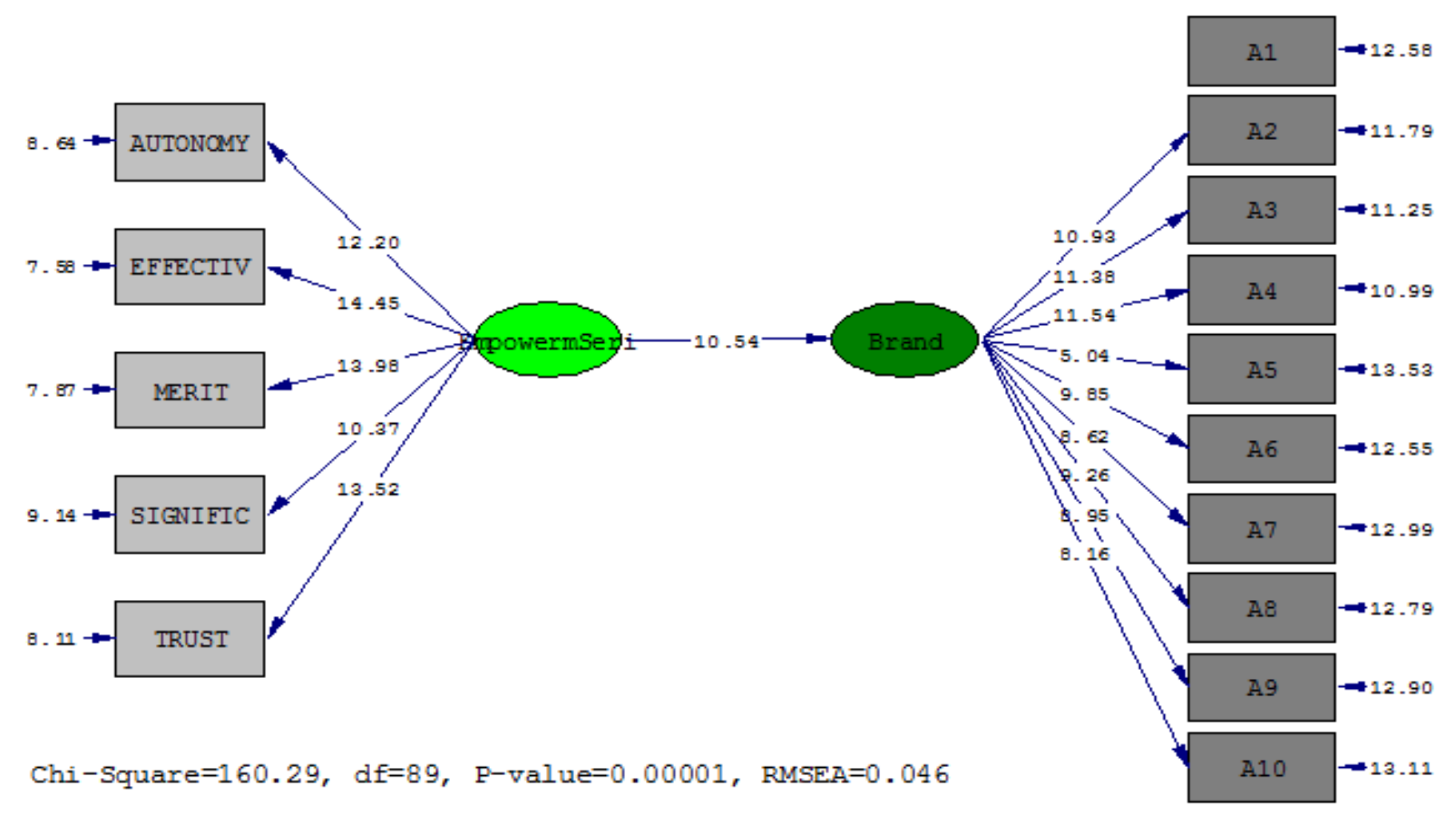

Figure 3. Measuring the general model and hypotheses results at significance level

Table 8

The Goodness of Fit Indices of Conceptual Model

\begin{tabular}{lllllll}
\hline $\mathrm{x} 2 / \mathrm{df}$ & RMSEA & RMR & GFI & CFI & NNFI & IFI \\
\hline 1.91 & 0.040 & 0.034 & 0.97 & 0.94 & 0.94 & 0.92 \\
\hline
\end{tabular}




\section{Results}

In order to investigate the causal relationship between dependent and independent variables and confirm the whole model, path analysis has been applied. In this research, path analysis has been conducted using LISREL 8.5. The results of LISREL outputs indicated that $\frac{x^{n}}{d f}$ is less than 3 and according to other goodness of fit indices, the model has a strong fit. Table 9 indicates the significance coefficient and the results of hypotheses. In the primary hypothesis, it was claimed that psychological empowerment has a positive and significant effect on brand equity. As shown in Table 9, the significance value between these two variables is equal to 10.54 and since this value is greater than 1.96, this hypothesis is confirmed. Furthermore, since the significance value is positive, this effect is direct.

Table 9

The Results of Hypotheses Test

\begin{tabular}{|c|c|c|c|}
\hline Hypotheses & Standard & Significance & Result \\
\hline \multicolumn{4}{|l|}{ Primary hypothesis } \\
\hline $\begin{array}{l}\text { Psychological empowerment has a positive and significant effect on brand equity of } \\
\text { Islamic Azad University, Bandar Abbas branch. }\end{array}$ & 0.82 & 10.54 & Confirmed \\
\hline \multicolumn{4}{|l|}{ Secondary hypotheses } \\
\hline $\begin{array}{l}\text { Merit has a positive and significant effect on brand equity of Islamic Azad University, } \\
\text { Bandar Abbas branch. }\end{array}$ & 0.74 & 12.20 & Confirmed \\
\hline $\begin{array}{l}\text { Effectiveness has a positive and significant effect on brand equity of Islamic Azad } \\
\text { University, Bandar Abbas branch. }\end{array}$ & 0.83 & 14.45 & Confirmed \\
\hline $\begin{array}{l}\text { Significance has a positive and significant effect on brand equity of Islamic Azad } \\
\text { University, Bandar Abbas branch. }\end{array}$ & 0.81 & 13.98 & Confirmed \\
\hline $\begin{array}{l}\text { Autonomy has a positive and significant effect on brand equity of Islamic Azad } \\
\text { University, Bandar Abbas branch. }\end{array}$ & 0.66 & 10.37 & Confirmed \\
\hline $\begin{array}{l}\text { Trust has a positive and significant effect on brand equity of Islamic Azad University, } \\
\text { Bandar Abbas branch. }\end{array}$ & 0.79 & 13.52 & Confirmed \\
\hline
\end{tabular}

\section{Conclusion}

Academics and marketing professionals have considered brand equity as a chance to create competitive advantages and future scientific flows and develop multilateral cooperation in the light of a knowledge environment. According to Aaker (2000), brand loyalty is the result of brand equity. The competitive advantage of institutions and companies with high brand equity includes opportunities for successful generalizations, flexibility in resisting rivals' increasing pressures, and putting obstacles in the way of rivals. High brand equity causes the receiver of educational services to believe the advertisements in all probability. Moreover, brand equity reduces the negative effects of choosing unattractive educational services and limits negative deductions after price rise.

Generally, brand equity increases the value for students, helps to create competitive situations, encourages consumers in advertisements and promotions, and accelerates the influence in the market.

Islamic Azad University, Bandar Abbas branch as a large educational and research center in Hormozgan Province can take a major step in creating social value of the university by discovering its internal capacities and considering the mental aspects of human resources in order to involve them in decision-making and develop a creativity-based atmosphere and 
intellectual interaction. The results of social value created by the students are to develop the university scientifically and give it mental value that can brand the university as a wellknown scientific center and increase its intangible assets.

According to the primary aim of the research, i.e., investigating the effect of psychological empowerment on brand equity and its hypotheses and results, in order to increase brand equity, employees' empowerment plans should be developed in such a way that they increase a sense of competency and by describing employees' responsibilities in detail as well as supporting and appreciating them (lead to employees' empowerment), the organizational learning should be provided. Holding case study meetings to increase the ability to make decision, analyze, and meditate in the form of educational and rehabilitation workshops before entering the organization is also recommended. Moreover, employees' empowerment obstacles in the organization should be identified and removed. Holding seminars, conferences, and meetings regularly on empowerment and reporting their results to policymakers is helpful as well. Furthermore, meritocracy in recruitment, promotion, etc. should be performed. It is also recommended that employees should be able to express their opinions and recommendations even if they are not accepted so that employees believe that their opinions or recommendations are applied to the strategic and operational decisions of the organization even if they are not used at that moment. Finally, in order to build a sense of trust between colleagues and create a positive mental atmosphere, internal information and news should be spread transparently so that this information flow prepares the ground for further cooperation within the organization.

\section{References}

Aaker, D. A. (2000). Managing brand equity: Capitalizing on the value of a brand name. DIANE Publishing Company: Collingdale, Pennsylvania.

Aaker, D. A., \& Joachimsthaler, E. (2009). Brand leadership. Pocket Books: New York City, New York.

Bowen, D. E., \& Lawler, E. E. (1992). The empowerment of service workers: What, why, how, and when. Sloan Management Review, 33(3), 31-39.

Goudarzi, A., \& Gominian, V. (2002). The principles, fundamentals, and theories of organizational atmosphere and culture. Isfahan Jihad Daneshgahi Publications: Isfahan, Iran.

Hafeznia, M. (2013). An introduction to methodology in humanities. SAMT Publications: Tehran, Iran.

Hayes, D. K., \& Ninemeier, J. D. (2008). Human resource management in the hospitality industry. John Wiley \& Sons: New York City, US.

Keller, K. L. (1993). Conceptualizing, measuring, and managing customer-based brand equity. Journal of Marketing, 57(1), $1-22$.

Keller, K. L. (2008). Strategic brand management: Building, measuring and managing brand equity. Pearson: New Jersey.

Kim, J-H., \& Hyun, Y. J. (2011). A model to investigate the influence of marketing-mix efforts and corporate image on brand equity in the IT software sector. Industrial Marketing Management, 40(3), 424-438.

Krishnan, B. C., \& Hartline, M. D. (2001). Brand equity: Is it more important in Services? Journal of Services Marketing, 15(5), 328-342.

Laverack, G. (2006). Improving health outcomes through community empowerment: A review of the literature. Journal of Health Population \& Nutrition, 24(1), 113-120.

McLagan, P., \& Nel, C. (1992). The age of participation: New governance for the workplace and the world. Berrett-Koehler Publishers: Oakland, US.

Miri, A., \& Sabzikaran, E. (2011). An investigation of factors effective in human resource empowerment of National Iranian Oil Product Distribution Company (NIOPDC). Journal of Development and Evolution Management, 3(6), 49-56.

Mohammadi, H. (2009). Factors effective in human resource empowerment. Taavon, 20(204-205), 1-19. 
Navehebrahim, A., \& Abdollahi, B. (2007). Employees' empowerment: The golden key of human resource management. Virayesh Publications: Tehran, Iran.

Noller, D. (1991). Beyond a buzzword: An empowered perspective in Andrews. Journal of Applied Psychology, 74(1), 152156.

Robbins, T. L., Crino, M. D., \& Fredendall, L. D. (2002). An integrative model of the empowerment process. Human Resource Management Review, 12(3), 419-443.

Spreitzer, G. M., \& Mishra, A. (1997). Survivor responses to downsizing: The mitigating effects of trust and empowerment. Southern California Studies Center, University of Southern California. Retrieved March 28, 2015 from http://www.usc.edu/dept/LAS/SC2/pdf/spreitzer.pdf

Thomas, K. W., \& Velthouse, B. A. (1990). Cognitive elements of empowerment: An "interpretive" model of intrinsic task motivation. The Academy of Management Review, 15(4), 666-681.

Toutian Esfahani, S. (2014). The relationship between empowerment and human resource productivity in Islamic Azad University (East Tehran Branch). Scientific and Research Journals Management System, 9(25), 29-42.

Van Osselaer, S. M. J., \& Alba, J. W. (2000). Consumer learning and brand equity. Journal of Consumer Research, 27(1), $1-16$.

Yoo, B., Donthu, N., \& Lee, S. (2000). An examination of selected marketing mix elements and brand equity. Journal of the Academy of Marketing Science, 28(2), 195-211. 